\title{
SATIRE AND THOUGHT IN FEAR AND LOATHING IN LAS VEGAS
}

\author{
DiLn FYTE:
}

Universidad do las Palmas

\section{ABSTRAC':}

This investigation employs a neo-Aristotelian metlod of plot inquiry in its analysis ol' llunter S. Thompson's satiric novel, Fear and loathing in Las Vegas, in order to illuminato the ways in which action, chatacter, and thought l'unction in expressing "Thompson's social criticism.

American society is the primary object of the satire, especially its capacily to believe in the idyllic vision contained in the myth of the American dream. "Tho toxt is also a parody ol" the myth of Iloratio Alger. The plot. inquiry concludes that the plots of action and charactor are subordinate to the plot of thought, which is soen here as the essential element in 'Thompson's satiric attatk upon American society at the end or the 1960 s.

\section{RESUMLN:}

El estudio de esta novela salirioa de Ilunter S. Jhompson se ha hecho siguiendo ol método neo-Aristotälico de anzilisis con el objectivo de descubrir lit fortma en que la acción, al personaje y su modo de pensar liuncionan como velículos do expresion de la crílica social de Thompson. lil principat objeto de esta sútira es la sociedad americana, y especialmente la capacjadsd de cista para creer en la vision idílica que contiene ol milo del sueño americano. El texto es tambion una parodia del mito de Jloratio Alger. E] análisis de la historia nos lleva a la conclusión de que el hilo de la acción y a] personaje están subordinados al pensamiento y que es oste último el elemento esencial del atitque satírico que Thompson hace de lat sociedad americana de los años 60 .

\section{KEY WORDS:}

Satire, Plot, Character, Action, Thought, the American Droam, Horatio Ager, las Vegas.

\section{PALABIIAS CIAVE:}

Sátira, secuencia de acción, personajo, pensamiento, el sueño antericano, lloratio Alger.

The United States was founded by slave-owners who wanted to be free, The doctrine ol Manifest Destiny gave divine sanction to the westward 
expansion. The continent was a vast, relatively unexplored natural resource. A land of opportunity. Rugged individualism and the Protestant othic were heralded as the righteous means to be employed in pursuit of the American dream. The novels of I Ioralio Alger best represent the formula necessary to the attainment of the American dream: honesty and hard work will pay off in the end: endurance and perseverance will be rewarded.

Melville's Moby-Dick is as much a novol about the whaling industry as it is an examination ol the American reality: a democracy. cnvisioned in the Pequod, actually an oligarchy, symbolized by the niggardly Quaker shipowners who, through their agent, the misguided Nab, aro capable of exerting a destructive omnipotence upon the masses, allegorized in Molville as the crew of the ship. Similarly, Huntor S. Thompson"s aGonzo» account ol the road trip taken by his narrative persona in Fear and Loathing in Las Vegas (1971) is as much a story aboul a trip to las Vegas as it is an indictment of American society. Like Melville's Islimael, the sole survivor who lives to tell the tale, Thompson's narrator, Raoul Duke, ulso survives his ordeal, but his extrication from the perverse madness of Jas Vogas is not an and to his ordeal, but rather, perhaps, a brief respite from the ongoing absurdity of American society: the stark contrast between reality and idcology:

...I felt like a monster reincarnation of Horatio $A$ lger... $\triangle$ Man on the Move, and just sick enough to be totally conlident. (204)

Melville and Thompson are, of course, worlds apart, yot they are bound together by a common thread: the vision of America that lurks within their lictton.

In looking at Ilunter S. Thompson's Fear and Loathing in Las Vegas: $A$ Savage Journey to the heart of the American Dream, the first question that jeeds to be asked is: what type of literature is it? Just as most crities would waste jittle time in labelling Gulliver's Travels a satire, so too do opinions of Thompson's toxt rarely stray from this clussification. The verso Satires of Forace had, on at least one level, a didaclic aim. The ridicule in such works functioned to effect morally constructive criticism: the secmingly light style of the satire belied the spoudogoloion, or «serious laughter,» which is the underlying purpose of the entertaining form. If 'Thompson's rollicking travel diary conceals a more serious intention, which it does in its debunking of the myth perpetuated by Horatio Alger, then scholars are correct in viewing the text as a satire. But is Fear and Loathing in Las Vegas lunctioning along didactic lines?

Elder Olson, writing about poetry in aWillium Empson, Contemporary Criticism, and Poetic Diction" (Modern Philology, 1950), differentiates didactic from mimetic, and the distinction he draws can be applied beyond the lorms of poetry to other realms of literature:

Didactic al]egory presents many superficind resemblanees to mimetic poetry; but the differences between them, while perhaps few and obscure, aro fundamental. Didactic poetry, whether allegorical or 
not, must always either propound a doctrino or determine a moral and emotional attitude toward a doctrine in such a way as 10 command action in accordance with it. The didactic structure must always, thereloro, involve explicitly or implicitly some pistic or argumentative element: either the poem argues the doctrine directly. or the argument is left to the reader, as in the case of parables and fables.(45-46)

Thompson's book is satiric but not, in the sense posited by Olson, didactic: Fear and Loathing in las Vegas satirizes a debauched American socicty where the notion still exists that an Algeresque «rags to riches» formula for success, founded upon principles of honesty, hard work, and perseverance, can be implemented in American society. Raoul Duke searches for the American dream; lie linds a nightmare. Ile exposes the fallacy ol the myth, but expounds no doctrine of his own. Thompson's agenda il reality: he satires the moral and political corruption of American society. The American dream, contingent as it is upon ethics, has no place in the hardnosed American society ol' 1971, us rendered by Thompson; in Duke's Las Vegals, the naive become victims. Thompson's vision of America satirizes both the naive and the victimizers.

In his Fiction and the Shape of Belief(1964) Sheldon Sacks deals with the evolution of the satiric genre, pointing to its movement away from its traditional, conlining precepts, Horatian didacticism presumably among them:

That there is a class called satire is a literary fact. But much like "tragedy," the term "satire" ages ago broke from its confinement as the discriminator of a literary type to escape into the freer verbal universe ol everyday English, with occasional forays into the unbridled world of journalese; Marilyn Monroe's death is atragic" in somewhat the same way in which Nikitit Khruscheleev is said to have a "harsh, sutiric porsonality."(5)

In liglut of Sacks's assertion, it is possible to view Thompson's text as a mixod medium: the numerous ludicrous depictions, especially the arotions of Duke and his attorney, are suggestive of a comic element. Duke's discovery ol the Amorican dream in modern America should have atragicm implications for a society that las inherited the legacy of Horatio Alger. Thompson's journalistic narrative technique, which includes reliarences to real people, places, and things as well as a section of toxt that is supposedly transcribed from Thompson's dictation by his editor, counterbalanec the bizarre actions of the text with a definite strain of naturalism, giving the satiric work of prose liction a very strong, non-fictional undertone. I mention Sacks for his assertion that satire is no longer conlined to its traditional characteristics, ind Olson for lis distinction between didactic and mimetic principles, in order to assume that Thompson's fear and Loathing in Las Vegas is a lictional prose satire not informed by didactic principles. With this premise, 1 hope to make sense of 'Thompson's text througl an analysis of its plot, 
availing myself' of IR.S. Crane's neo-Aristotelian method of plot inquiry, which he limits to novels and dramas enot construeted on didactic principlesp(66).

At first glance it may seem reasonable to dismiss Thompson's plot as an incoherent jumble of digressions, which is certainly not the case. Thompson's narrator, Rnoul Duke, along with his traveling companion, the three hundred pound Samoan attorney. Dr. Gonzo, runs a reckless rampage: through the desert to Las Vegas, separating and reuniting, back out to the desert and back again to Las Vogas, ending with Duke outside the men's room at the Colorado airport. Purt One of Fear and Loathing encompasses the desert trek from California to Las Vegas, where Duke has been assigned to cover an olT-the-roud motorcycle race, the Mint 400 , for a New York sporting publication. The pair separate: Dr. Gonzo returns to California by plane, while Duke flees Las Vegas in the rented convertible, making it as lar as the barren California desert before a phone conversation with Dr. Gonzo persuades him to return to Las Vegas, where Duke will then cover the National District Attorneys' Conf'erence on Narcotics and Dangerous Drugs at the Flamingo Hotel. Part One ends with Duke, in the same desert whero the narrative began, contemplating a return to las Vegas. Part Two begins, thgain in the desert, and encompasses the return to Las Vegas, the DA's Conl'erence, Duke's recognition of the American dream, and his final exit to Colorado. 'The plot of action centers upon Las Vegas and Duke's two main assignments: the Mint 400 and the National District Attorneys' Conlerence. These actions do not appear to rise out of each othor, nor do they seem united in a progression; yet, when synthesized by the plot of thought, and inlormed by the plot of character, theso actions become significant and can be seen as coherent parts ol" the whole of 'Thompson's novel.

Both the idea of the American dream and that of the Horatio Alger myth function to inform the plot ol thought. "The combined thought of these two ideas might be something like this: in the land of opportunity, success can be achieved through perseverance, honesty, and hard work. Abe Lincoln went from a log cabin to the Whito House: everyone, ifscluding the poor, has at least the chance to "make it» in America.

Jass Vegas is 'Thompson's symbol of American society, where corruption is rife, and money is the measure of success. Duke's journey throughout the story assaults the notion of virtue that permeates the Horatio Alger versions ol" "rags to riches" success. Duke explains the modern reality of the American droam to his Samoan attorney:

"You Samoans are all the same," I lold him. "You have no faith in the essential decency of the white man's culture. Jesus, just one hour ago we were sitting over thore in that stinking bajginio, stone broke and paralyzed for the weekend, when a call comes through from some total stranger in Now York, telling me to go to Las Vegas and expenses be damned-ind thon he sends me over to some oflice in Beverly Hills 
where another total stranger gives me $\$ 300$ raw cash for no reason at all...l tell you, my man, this is the American Dream in action. We'd be lools not to ride this strange torpedo all the way out to the end. (11) The thought contained in this passage synthesizes the plot of action: the initial trip to Las Vegas is no longer for the purpose ol covering the Mint 400: But what was the story? Nobody had bothered to say. So we would have to drum it up on our own. Free Enterprise. The American Dream. Iloratio Alger gone mad on drugs in I.as Vegas. Do it now: pure Gonzo journalism. (12)

The journey to Las Vegas, without this accompanying plot of thought. would indeed appear to be an insignificant junket, a mimetic rendering of little seriousness. Yet by motivating his action along these lines, Thompson achieves a satiric subversion of the American dream: Duke will «milk this free ridow as far as he can taking advantage of the system, without virtue. honesty, or hard work.

Thompson disenlranclises his narrative persona from the American society that is the primary object of this satire. «We were somewhere around Barstow on the edge of the desert when the drugs began to take holdw(3). This is the first sentence in the text, and it suecessfully introduces the character of Duke as being isolated from society in the physical setting, depicting him as mentally alienated as well, the drug use being looked upon in 1971 as an anti-social behavior, a rejection of American values:

The trunk ol the car looked like a mobile police narcotics lab. We had two bags ol grass, seventy-live pellets of mescaline. five sheets of high-powered blotter acid, a salt shaker half full of cocaine, and a whole galaxy of multi-colored uppers, downers, screamers, lauglers... and a quart of tequila, a quart of rum, a case of Budweiser, at pint ol' raw ether and two dozen amyls. (4)

The drugs play an important part in the characterization of Duke. As the "monster reincarnation of Horatio Alger»(204), Duko can "make it," can "pull it off," despite the socially accepted view of the irresponsibility inlerent in someone who blatantly impairs his consciousness. Horatio Alger certainly would not lave had his American hero reach for the American dream with a trunkload of illegal narcotics and psychedelics. But Thompson's las Vegas is no stronghold of Puritan naivete. "In a town full ol bedrock crazies, nobody even notices an acid freakm(24). In a city that bears litlle resemblance to America's own pre-conceived notion of reality, Duke feols the need to achallenge the bastards on their own turf»(17). If the culture is depraved, he will become even more depraved, and still «get by.» And to achieve this with someone else footing the bill, well, this is part of the modern version of the American dream in action.

Before thoy ever actually arrive in Las Vegas, Duke and Gonzo pick up a hitchhiker. As part of the sequence of actions rendered by Thompson. this incident seems insignilicant, yet its integration in the plot of thought turns this incident into a satirie look at the naive American. It is significant that 
the incident takes place outside Las Vegas, which for 'Thompson signifies the utter corruption of the American ethic. Duke describes the hitehhiker as a "poor Okie kid... rumning up to the car with a big grin on his lace, saying, “Hot damn! I never rode in a convertible before!n(5) Thompson is contrasting the naive with the hardened, enlightened cynicism ol"his protagonist and stooge companion, Dr. Gonzo, who reinforces the distinction:

"We're your friends," said my attorncy. "We're not like the others.» (5)

Duke tries to explain to the kid that he and Gonzo are on their way to Las Vegas to find the American dream, but their bizarre behavior - druginduced hallucinations at one hundred miles per hour across the desert, so terrorize the hitchiker that he jumps out of the car and flecs:

his leet hit the asplaalt and he started running back towards Baker.

Out in the middle: of the desert, not a tree in sight. (19)

The hilchhiker, with his all-Americtun innocence, would, perhaps, be better suited to a Horatio AIgor plot than would Duke and Dr. Gonzo. This is Thompson's point: tho naive do not make it in at capitalist America fraught with fraud and decoption. Just as Duke, in his subversive, anti-social approach toward society, is the monster reincarnation of Horatio Alger, so too is Las Vegas tho monster reincarnation of America as the land of opportunity. It is the plot ol thought as the synthesizing agent that gives signilicance to the actions in the desert that precede Duke's encounter with Las Vegas society.

Belore thrusting Duke into the grotesque reality of Las Vegas, Thompson issues some journalistic prose which lends an aura of realism to the bizarre story-line, intimating that the achievement of the American dream is no longer contingent upon the prerequisites enlabled in the myth of Horatio Alger:

A very painful experience in every way, a proper end to the sixties: Timothy Leary a prisoner of Eldridge Cleaver in Atgeria, Bob Dylan clipping coupons in Greenwich Village, both Kennedys nurdered by mutants, Owsley folding napkins on Terminal Island, and finally Cassius/Ali belted ineredibly olf his pedestal by a human hamburger. a man on the verge of death. Joe lirazier, like Nixon. had finally prevailed for reasons that people like me refused to understind - at least not out loud.

... But that was some other era, burned out and long gone from the brutish realities of this foul year of Our Lord. 1971. A lot of things had changed in those years. (22-23)

Indeed. $A$ land of opportunity lor beasts and criminals. Those working presumably in good conscience lor freedom and enlightenment dead or behind bars, and Joe Frazier, the Philadelphia brawler, and Riclard Nixon, it crook even before the advent of Watergate, rise to the pinnacles of Anerican sociely lormerly reserved, in the American sentiment at least, for role models such as "Gentleman Jim» and «lfonest Abe,» Before bringing 
his plot to Jass Vegas, Thompson has successlully luid the groundwork for his assault upon the Amorican dream. He does it by means of the thought expressed through Duke's narrative.

Part One of Fear and Loathing moves out of the desert to Las Vegas, where Duke, whose real intention is to find the American dream, will "cover" the Mint 400 ,

the richest off-the-road race lor motorcycles and dune-buggies in the? history of organized sport - a lantastic spectacle in honor of some: fatback grossero named Det Webb, who owns the luxurious Mint Jlotel in the heart of downtown Vegas.... (9)

Duke and Gonzo check into the Mint Hotel, where Thompson confronts his characters with a taste of political realism:

The 'TV news was about the lans Invasion - a series ol' borrifying disasters: explosions and twisted wreckage, men flecing in terror, Pentagon gonerals babbling insane lies. c'l'urn that shitoll?"» screamed my altorney. «Let's get out of here!n(29)

Duke and Gonzo leave the trotel for the streets of Las Vegas, and Thompson continues to build upon his plot of thought by contrasting the horrid reality of the Vietnam war with the hedonistic mores of Las Vegas culture:

Turn up the radio. Turn up the tape machine. Look into the sunset up ahead. lioll down the windows for a better taste of the cool desert wind. Ah yos. 'This is what it's all about. 'Total control now. 'Tooling along the main drag on a Saturday night in Las Vegas, two good old boys in a fireapple-red convertible... stoned, twisted... Good People. (29)

Harsh political realities aside. Duke and Gonzo seem actimated to the Vegas life only momentarily, until their calm reserve is broken by Thompson's sociat criticism, issued through the car radio to the tune ol «'The Batte Hymn of Licutenant Calley»:

"... as we go marching on...

When I reach my linal campground in that land beyond the sun. And the Great Commander asks me...

(What did he ask you. Rusty?)

...) Jid you light or did you run?

(And what did you tell him. liusty?)

We respofsded to their rifle tire with overything we had.... (29)

"Rusty" Calley presiled over a civilian massacre that included the butchering of Vietnamese women and children, and any attempt by society to glorify such an cact of war» is too much for Duke to handle:

No! I can't be hearing this! It must be the drug. Thatnk christ he IDr. Gonzol can't hear this music, I thought. It would drive him into a rilcist fronzy. (32)

Thompson uses this absurd song to further the agenda contained in the plot of thought: naive Americans, such ats the hitchbiker, who aro suscep- 
tible to such a blatant whitewasl of the heinous facts, are also prone to believe in the outdated Horatio Alger creed, thinking it still comes with a slice of apple pic. Las Vegas becomes the symbolic landscape wherein Thompson will choreograph the moral demise of the American dream. The gambling casinos signily the "rags to riches" opportunism available in America, but gone from the formula is the Alger ethic: those who attempt to «make it» in Las Vegas are seen as one-armed masturbators embraced in a macabre dance witl slot machines. The Mint 400 is Thompson's vehicle: it allows Duke an all expense paid entrance into the seamy underbelly of American society, as well as providing a contrast to the District Attorneys' Conference on the drug menace in Part Two.

Duke rides "this strange torpedo»(11), his subverted version of the American dream in action, at the expense of the publishing world, who, in the interests of making money, see no distinction between a dune buggy race and a conference aimed at exploring the problem of drugs in American society. In a culture where you can turn off the Lios Invasion and tune in the "Battle of Lt. Calley» the media present a distorted view of society, which, as 'Thompson will show with the District Attorneys' Conference, reflects the distorted views of its audience.

The Mint 400, the off-the-road race, represents non-mainstream America. Thompson achieves this representation with the aboney, middle-aged hoodlum wearing a Harley-Davidson T-shirtw(35), who, after slapping his "old lady" around and taking a bus to Las Vegas in order to attend the race, wakes up disoriented in downtown Las Vegas, asking himself, "O Jesus, loere we go again: Who's divoreed me this time?»(35) Unlike the District Attorneys" Conference, which attratts law enforcement officials from all over the country - the mainstream- the Mint 400 draws the opposite type of crowd, the whoodlums":

We all understood. In some circles, the «Mint 400 " is a far, far better thing than the Super Bowl, the Kentucky Derby and the Lower Oakland Roller Derby linals all rolled into one. This race attracts a very special breed, and our man in the Harley T-shirt was clearly one of them. (36)

It is interesting that, unlike the cops who attend the Drug Conference. and are unable to see Duke's behavior for what it is, the people at the Mint 400 sense Duke's depravity:

"What's the entry lee?" I asked the desk man.

"Two fifty," he said.

"What if I told you I laad a Vincent Black Shadow?"

lle stared up at me, saying nothing, not friendly. I noticed he was wearing a 38 revolver on his belt. "l'orget it.» I said. «My driver's sick, anyway.»

His eyes narrowed. "Your driver ain't the only one sick around here, buddy." (33) 
One of Thompson's main thrusts in juxtaposing Duke's coverage assignments is to show how naive mainstream America can be. Duke, in the midst of America's law enforcement agents, so-called experts on the narcotics menace, call push his anti-social behavior to the limit, without detection. It is in this sense that he achallenges the bastards on thojr own turf»(17) and succeeds. But Duke's attempt to cover the motorcycle race turns into a farce: ... by the time they'd sent off the first hundred (with still another hundred to gol, our visibility was down to something like fifty feet... None of us realized, at the time, that this was the last we would see of the "rabulous Mint 400 -(38)

This is the last of the race for Thompson's readers us welt, but the race was only secondary to Duke's intended mission to lind the American dream while riding out his own twisted version of it. The Mint 400 functions in the text as a symbolic counterpoint to the National DA's Conference that dominates Part Two of the text. Both sequences in the plot of action gain significance, and coherence, when synthesizod by the plot of thought that runs through the work.

The remainder of Part One chronicles the exploits of Duke and Gonzo in various Las Vegas nightspots. These escapades help Thompson achieve his characterization of Duke as a subverted Horatio Alger figure. But this plot of character, which is it satiric recreation of the Alger ligure, gains significance only through its relationship with the plot of thought. At the Desert inn the manic pair force their way into the grand ballroom, where «Debbie Reynolds was yukking across the stage in a si]ver $A$ fro wig... to the tune of" "Sergeant Pepper,» I'rom the golden trumpet of Harry James»(44). The album aSergeant Pepper» contains an infamous pacan to the drug culture, "lucy in the Sky with Diamonds," The Bentles, at that time. were looked upen as avatars of the drug culture. Thompson is effecting a ludicrous imago here, showing how mainstream America is capable of subverting, and ignoring moaning, in this case for tho purpose of l'rivolous spectacle. Jintertainment. This image is not too far removed from the song about L.t. Calley.

There is one other signilicant stop made by the fronzied pair during Part One: their ill-fited trip to Circus-Circus, the casino where Duke wilt eventually recognize the American dream in Part Two, and where in Part One, they have a foreboding sonse of their proximity, while recoiling from the madness of the place, duc to the «fiendish intensity»(47) of a mescaline trip:

"I hate to say this," silid my attorney as we sat down at the MerryGo-liound Bar on the second balrony, abut this place is getting to me. I think l'm getting the Fear.s "Nonsense," I said. "We eume out here to lind the American Dream, and now that we're right in the vortex you want to quil.» 1 grabbed his bicep and squeozed. "You must realize," I said, "that we've found the main nerve,m $(47-48)$ 
Duke's lengthy description of Circus-Circus epitomizes modern America's long descent from the Puritan's idyllic conception of a «city upon a hill»: The Circus-Circus is what the whole hep world would be doing on Saturday night if the Nazis had won the war. This is the Sixth Reich. The ground floor is full of gambling tables, like all the other casinos... but the place is about four stories high, in the style of a circus tent, and all manner of strange County-Fair/Polish Carnival madness is going on up in this space. Right above the gambling tables the Forty Flying Carazito Brothers are doing a high-wire trapeze act, along with four muzzled Wolverines and the Six Nymphet Sisters from San Diego... so you're down on the main floor playing blackjack, and the stakes are getting high when suddenly you chance to look up, and there, right smack above your head is a half-naked fourteen-year-old girl being chased through the air by a snarling wolverine, which is suddenly locked in a death battle with two silver-painted Polacks who come swinging down from opposite balconies and meet in mid-air on the wolverine's neck... This madness goes on and on. but nobody seems to notice. The gambling action runs twenty-four hours a day on the main lloor, and the circus never ends. Meanwhile, on all the upstairs balconies, the customers are being hustled by every conceivable kind of bizarre shuck. All kinds of funhouse-type booths. Shoot the pasties off the nipples of a ten-loot bull-dyke and win a cottoncandy goat... No, this town is not good lor psychedelic drugs. Reality itself is too twisted. (46-47)

It is against such a carnivalesque backdrop as Circus-Circus that Duke eatches a glimpse of the sickly reality of the modern day American dream as it is pursued by masses of opportunity-minded Americans:

Now ofr the escalator and into the casino, big crowds still tight around the crap tables. Who are these people? These faces! Where do they come from? They look like caricatures of used-car dealers from Dallas. But they're real. And, sweet Jesus, there are a liell of a lot of them - still screaming around these desert-city crap tables at fourthirty on a Sunday morning. Still humping tho American Dream, that vision of the Big Winner somehow emerging from the last-minute pre-dawn chaos of a stale Vegas casino. (57)

Dr. Gonzo, still reeling from the bad vibrations he'd sensed at CircusCircus, «flips out» on acid, and he and Duke separate. This is followed by Duke's narrative digression, a reminiscence of the failed move toward enlightenment attempted by the sixties generation:

We had all the momentum; we were riding the erest of a high and beautiful wave....

So now, less than five years later, you can go up on a steep hill in Las Vegas and look West, and with the right kind of eyes you can almost see the high-ivater mark - that place where the wave finally broke and rolled back. (68) 
This is a continuation of the plot of thought, strategically placed in the text to synthesize the plot of action, which makes its shift in the sentence immediately lollowing the digression; «The decision to flee came suddenlyw(69). Duke panies, aghast at the madness ol his actions, the madness of Las Vegas, yet still altuned to the theme he has been subverting: «llow would Horatio Alger handle this situalion?w(70) Alger envisioned society as virtuous and forgiving. Thompson allows his "monster reincarnation" no such luxury:

Sympathy?

Not for me. No mercy for the criminal freak in Las Vegas. This place is like the Army: the shark ethic prevails - cat the wounded. In at closed society where everybody's guilty, the only erime is getting caught. In a world of thieves, the only final sin is stupidity. (72)

With this in mind Duke llees las Vegas, but is llight is complicated by lis encounters with the llighway Patrol, and with the hitchhiker, until, in a moment ol erisis, Duke calls Dr. Gonzo who, back in L.A., reminds Duke of the assignment involving the DA's Conference. Duke recognizes some twisted force of destiny at work determining his actions: this thought precipitates his return to Las Vegas, and the resumption of the search for the American droam:

Never cross the Great Magnet. I understood this now... and with this understanding came a sense of almost terminal relief. Yes, I would go back to Vegas. Slip the Kid and confound the CIIP by moving Last again, instead of West. This would be the shrewdest move of my lile.

Back to Vegas and sign up for the Drugs and Narcotics conference; me and a thousand pigs. Why not? Move conlidently into their midst. Registor at the liamingo and have the White Caddy sent over at once.

Do it right; remember Horatio Alger....(95)

This is Duke's subverted adherence to the ethical perseverance that marks the Alger myth. In Alger's novels, hard work and a virtuous character are generally the means toward success only in conjunction with a sstroke of good fortune." Once Duke finally endeavors to persevere. he has an intimation of his ehanging fortune, when he orders a beer:

«Ballantine Ale," I said... a very mystic long shot, unknown between

Newark and San Francisco.

He served it up, ice-cold.

I relaxed. Suddenly everything was going right: I was linally getting the breaks.(95-96)

Ilaving thus depicted Duke's subverted resolve, Thompson makes an end to Part One of his text. The plot of action does not shift due to probability or necessity, but rather duc to the plot of thought issued through the satiric persona of Raoul Duke: in his parody of the Alger myth. Thompson effectively satirizes the deluded American beliel in the myth of the American dream.

Part Two of Fear and Loathing begins in the desert, moves to Las Vegas and the Conference, shifts over to Circus-Cireus, and ends with Duke's self- 
recognition at the Aspen airport. The other myriad incidents that occur in the text help define the plot of character, which really includes Duke alone, and which is informed, as are the actions, by the plot of thought: the minor incidents that chart Duke's debauchery are in keeping with the subverted role that Thompson has established for his character.

Checking into the hotel from which he will cover the Conference, Duke encounters a party of cops, unable to check in and belligerent at the clerical error in the hotel's bureaucracy that is responsible for their inconvenience. They are in the right, and Duke is there registering under false pretenses, yot he is able to circumvant their public display of ineptitude, and leaves them wallowing in their own discomliture as he goes to claim his room:

I nodded and smiled, half-watching the stunned reaction of the copcrowd right next to me. They were stupid with shock. Here they were arguing with every piece of leverage they could command, for a room they'd already paid for - and suddenly their whole act gets sideswiped by some crusty drifter who looks like something out of an upper-Michigan hobo jungle. And he checks in with a handful of credit cards! Jesus! What's happening in this world" (108)

Good guys can finish last in American socicty: Thompson illustrates this in the scene at the front desk, but the action itself is only significant as a setting in which the character of Duke can be portrayed. Moreover, his character, the negative portrnyal of the "rags to riches» virtuoso, is determined throughout by the plot of thought. The actions allow Thompson to achieve the characterization necessary to convey the satiric venom contained in his plot of thought.

The Drug Conference draws a different crowd than did the Mint 400:

These were the people who made my attorney nervous. Like most

Californians, he was shockod to actually see these people from The

Outback. Here was the cop-cream from Middle America... and, Jesus, they looked and talked like a gang of drunken pig farmers! (140)

The Drug Conference is the culmination of Thompson's story, an illustration of the lengths to which Duke must go in his effort to lully subvert the perseverant ethic of Horatio Alger. Duke explains the ludicrous irony and imminent peril of the assignment:

But this time our very presence would be an outrage. We would be attending the conference under false pretenses and dealing, from the start, with a crowd that was convened for the stated purpose of putting people like us in jail. We were the Menace - not in disguise, but stone-obvious drug abusers, with a llagrantly cranked-up act that we intended to push all the way to the limit... (109)

The DA's Conference poses no problem for Duke and Dr. Gonzo: they "challenge the bastards on their own turf" and succeed. This is not much of a problem for Duke, who depicts the members of the conference as naive, totally ignorant of the reulities of the drug culture, and, generally, behind the times. Duke's atlack upon the sound system signilies the outdatedness 
of American society in relation to the drug culture. Duke compares the acoustics at it concert, "where a dozen stone-broke freaks from the Seatle Liberation Front had assembled a sound system that carricd every small note of an acoustic guitar - oven a cough or the sound of a boot dropping on the stage- to half-dead acid victims huddled undor bushes a half mile awaym(138), to the sound system used by the DA's Conference, a sound system that «looked like something Ulysses $\mathrm{S}$. Grant might have triggered up to address his troops during the Seige of Vicksburgn(138). Duke's «trashing» of the sound system effectively depicts the law enforcement people as employing some sort of anachronistic mothod in its attempt to discern and then deal with the drug problem in American society. Duke "makes it," getting by in a culture alien to his own ideology, but in his recognition there is a grim reality:

It had been a waste of time, a lame fuckaround that was only -in clear retrospect - a cheap excuse for a thousand cops to spend a few days in Las Vogas and lay tho bill on the tax-payers. Nobody had learned anything —or at least nothing new. Except maybe me... and all I learned was that the National District Attorneys' Association is about ten years behind the grim truth and harsh kinetic realities of what they have only just recently learned to call athe Drug Cufture» in this foul year of Our Lord, 1971. (201)

Just as the DA's Conference provided the backdrop for Duke to run his subverted Horatio Alger act to fruition, the Circus-Circus is the pace where Duke finally discovers the American dream. Ilis discovery is tinged with resignation, perhaps because it is an indictment of how debased the conception of the American dream las become in American society:

.... You found the American Dream?"

he said. «In this town?"

I nodded. "We're sitting on the main nerve right now," I said. "You remember the story the manager told us about the owner of this place? Ilow he always wanted to run away and join the circus when he was a kid?"

Bruce ordered two more beers. He lonked over the casino for a moment, then shrugged. «Yeah, I see what you mean," he said. "Now the bastard has his own circus, and a license to steal, too." He nodded. "You're right -he's the model."

«Absolutely,» I said. «It's pure Horatio Alger, all the way down to his attitude. I tried to bave a talk with him, but some heavy-sounding dyke who claimed to be his Executive Secretary told me to fuck olf. She said be hates the press worse than anything else in America." "Him and Spiro Agnew," Bruce muttered. (191)

The plot shilt from the conference to Circus-Circus hardly arises out of any probability or necessity, coming as it does with Duke's attempt to purchase a trained, though heavily incbriated, circus ape. But the shift in action can be looked upon as a colierent progression embodying the plot of 
thought as expressed througl the "Gonzo" narrator, Duke. The realization of the American dream is ironjcally anti-climactic, issued brusquely in a spare bit of dialogue between Duke and his Canadian litiend Bruce. The lengthy and grotesque description of Circus-Circus given in Part One becomes the locus of Duke's realization of the modern day American dream. After uncovering the sordid reality of American society as symbolized by Las Vegas, and particularly Circus-Circus, Duke realizes that the American dream is to own and perpetuate the immoral institutions that llourish in America. Thompson links the sordid reality of Las Vegas to American polities:

A little bit of this town goes a very long way. Alter five days in Vegas you feel like you've been here for live years. Some people say they like it -but then some people like Nixon, too. He would have made a perfect Mayor for this town; with John Mitchell as Sherilf and Agnew as Master of Sewers. (193)

Having experienced lirst-hand, and survived, the grotesque carnival of Las Vegas, Duke makes his exit. the last lines of the book crystallizing the plot of thought that has synthosized the plots of chatacter and action:

... and by the time I got to the bar my heart was full of joy. I lelt like a monster reincarnation of IJoratio Alger... A Man on the Move, and just sick enough to be totally confident. (204)

Duke recognizes the antithetical nature of his actions as they relate to the ethical code in the Alger myth. He can make it in America without virtue. Perhaps this explains his conlidence. The satire attacks the incongruity between thought and deed in an American society detached from its moral bearings yet still attempting to perpetuate an idyllic self-image. In realizing that the American droam is a nightmare, Duke explodes the myth. In so doing, he invalidates the nostalgic attributes of virtue against which the masses of Americans judge their actions, and Duke's. Duke's move toward confidence does not mean that this text is primarily a plot of character. Duke is Thompson's satiric persona. Ilis actions througlout the text are diametrically opposed to the moralizing tone of his verbal expression. His recognition at the close of the book comes just after he has impersonated a priest in order to obtain a controlled narcotic substance. There may be a stragic» enlightenment, but certainly no concrete evidence of change in the character of Raoul Duke. The extreme discrepancy between his words and deeds make any claim toward moral change suspect. This is a plot of thought, inextricably linked with Thompson's satiric form.

Shcldon Sacks assumes that «satires aro works which ridicule particular men, the institutions of men, traits presumed to be in all men, or any combination ol the three (3). Thompson's text obviously lulfils this requirement. Sacks's assertion is contingent upon his claim that all the parts of the whole must contribute to the ridicule, must smaximize the ridicule of some combination of the three objects of satiren(7). Sacks lurther asserts that these sobjects of satire are extant only outside the fictional world created 
in the book.... $(7)$ Thus, the entire sequence of actions undertaken by Duke contribute to one of the objects of 'Thompson's satire, the novels of Horatio Alger. Duke's actions are a satiric parody of the Iloratio Alger figure in search of the American dream. This alone gives coherence to the text. American society is also an external object of 'Thompson's satire. The journalist and the publishing industry, the naive as well as the cynically enlightened, social and political institutions - all of these external objects of satire have fictional counterparts in Thompson's text. Aspects of thought, action and character are integrated to maximize the ridicule directed at the different combinations of the three objects of satire.

Where Thompson's text tends to stray from Sucks's definition of satire is in its inclusion of factual material. Nixon, Agnew, and Alger are all used by Thompson to effect the satire. They are external objects of the satire, yet they are ridiculed within the text. Rather than detracting from the strength of the satire, lowever, these factual inclusion enhance Thompson's satiric prose, by giving the tale a strong undertone of authenticity. These factual inclusions can be looked upon as afacilitating the ability of the fictional creations to ridicule the objects, of whatever sort)(Sacks,8).

In examining the plot structure of Hunter S. Thompson's Fear and Loathing in Las Vegas: A Savage Journey to the heart of the American Dream, with the premise that it is a satire not constructed upon didactic principles, it becomes clear that the plot of thought is the synthesizing element in the integration of action, character and thought that work togather, as a coherent whole, to maximize the objects of the satire: American society and its people's distorted conception of itself as cmbodicd in the cultural myths of Horatio Alger and the Amorican dream. 


\section{BIBLIOGRAFIA}

CRANE, R.S. Critics and Criticism (abridged edition). Chicago: Chicago UP, 1952.

OLSON, Elder. «William Empson, Contemporary Criticism, and Poetic Diction.» Modern Philology, 1950, reprinted in Critics and Criticism, ed. Crane, pp 24-61.

SACKS, Sheldon. Fiction and the Shape of Belief. CA: Berkeley UP, 1964.

THOMPSON, Hunter S. Fear and Loathing in Las Vegas: A Savage Journey to the heart of the American Dream. New York: Vintage Books (Random House), 1971. 